\title{
保育園における幼児の活動水準に関する研究
}

\author{
吉沢茂弘* 本多宏子** 㴚原 誠 ${ }^{* * *}$ 中村 仲***
}

\section{A STUDY ON PHYSICAL ACTIVITY LEVELS OF YOUNG CHILDREN IN THE NURSERY SCHOOL}

\author{
Shigehiro Yoshizawa, Hiroko Honda, Makoto Urushibara \\ and NAKa NAKAMURA
}

\begin{abstract}
Six male and seven female children, aged five or six years, ran on the flat treadmill increasing running speeds every two minutes by $20 \mathrm{~m} / \mathrm{min}$ till their subjective exhaustions. The first steps were started with the speeds of 80 or $100 \mathrm{~m} / \mathrm{min}$ and the rest periods of 30 seconds were inserted between each successive step for the blood sampling. Expired airs for the determination of oxygen uptakes were collected during the last 30 seconds of every stage. Heart rates were recorded for each subject throughout the whole test session.

Two male and two female subjects were selected in order to determine their physical activity levels in the nursery school. Their heart rates were recorded from Monday to Saturday in a given week.

Analyses of physical activity patterns were tried by relating heart rate levels to circulorespiratory variables which were equivalent to 3 or $4 \mathrm{mmol} / \mathrm{l}$ blood lactate concentration ( $3 \mathrm{~m} \mathrm{MLA}$ or $4 \mathrm{~m} \mathrm{MLA}$ ).

By so doing, the following results were obtained :

1) Mean values of blood lactate concentrations observed immediately after the cessation of the last exhaustive steps were $5.16 \mathrm{~m}$ MLA for males and $4.70 \mathrm{~m} \mathrm{MLA}$ for females.

2) Relative values of heart rate to 3 and $4 \mathrm{mMLA}$ against maximal heart rate (\% HRmax-3 $\mathrm{m} \mathrm{MLA}$ and \% HRmax-4 m MLA) were respectively $92.2 \% \mathrm{HRmax}-3 \mathrm{~m} \mathrm{MLA}$ and 97.5\% HRmax $-4 \mathrm{~m}$ MLA for males and $94.9 \% \mathrm{HRmax}-3 \mathrm{~m}$ MLA and $98.2 \% \mathrm{HRmax}-4 \mathrm{~m}$ MLA for females.

The corresponding relative values of oxygen uptakes were $85.2 \% \dot{\mathrm{V}}_{2} \max -3 \mathrm{~m} \mathrm{MLA}$ and $94.3 \% \dot{\mathrm{V}}_{\mathrm{o}_{2}} \max -4 \mathrm{~m} \mathrm{MLA}$ for males and $89.7 \% \dot{\mathrm{V}}_{2} \max -3 \mathrm{~m} \mathrm{MLA}$ and $96 \% \dot{\mathrm{V}}_{2} \max -4 \mathrm{~m}$ MLA for females.

3) Mean values of heart rate recorded in the nursery through a given week except Sunday ranged from 89 to 114 beats $/ \mathrm{min}$ for males and 106 to 126 beats $/ \mathrm{min}$ for females. In the relative value of a heart rate against the heart rate equivalent to $4 \mathrm{mMLA}$, that is, $\% \mathrm{HR} 4 \mathrm{~m} \mathrm{MLA}$ these values correspond to $44 \sim 57 \% \mathrm{HR} 4 \mathrm{~m} \mathrm{MLA}$ and $57 \sim 67 \% \mathrm{HR} 4 \mathrm{~m} \mathrm{MLA}$ respectively.

4) Accumulated duration time: Their hearts beat higher than 160 beats/min, except in the case of $800 \mathrm{~m}$ endurance run (only $0 \sim 4$ and $0 \sim 6$ minutes for males and $0 \sim 6$ and $4 \sim 21$ (touch of tachycardia) minutes for females).

Percentages of accumulated duration time lower than 120 beats/min occupied $72 \sim 94 \%$ and $77 \sim 91 \%$ of 6 or 7 -hour nursing time for males and $51 \sim 91 \%$ and $51 \sim 78 \%$ for females.
\end{abstract}

*宇都宮大学教育学部 干321 宇都宮市峰町350

**国学院大学栃木知期大学. 干328 栃木市平井町 608

***栃木県トレーニングセンター テ321-01 宇都宮市西田川町1805
Faculty of Education, Utsunomiya University 350 Mine-machi Utsunomiya 321

Kokugakuin-Tochigi Junior College 608 Hirai-cho Tochigi 328

Tochigi-ken Training Center 1805 Nishikawada-machi Utsunomiya 321-01 
5) Absolute and relative values of mean heart rates in $800 \mathrm{~m}$ endurance run ranged from 183 beats/min (Net 83\% HRmax, 90\% HR 4 m MLA) to 199 beats/min (Net $98 \%$ HRmax, $104 \%$ HR $4 \mathrm{~m} \mathrm{MLA}$ ) for males and from 172 beats/min (Net 77\% HRmax, 92\% HR $4 \mathrm{~m} \mathrm{MLA}$ ) to 196 beats/min (Net $92 \%$ HRmax, $96 \%$ HR 4 m MLA), though the duration times were short.

6) Optimal intensity of work load was proposed to be the heart rate level of at least 190 beats/min for favourable development and/or improvement of the circulo-respiratory system in young children.

(Jpn. J. Phys. Fitness Sports Med. 1988, $37: 158 \sim 171$ )

key words : young chidren, nursery, $4 \mathrm{~m} \operatorname{MLA}(\mathrm{AT})$, physical activity patterns

\section{I. 粕}

著者らは，これまで一貫して幼児の有酸素的作 業能力に関する研究を進めてきた，その過程で， 体重当り最大酸素摂取量 $\left(\dot{\mathrm{V}}_{2} \mathrm{max} / \mathrm{TBM}\right)$ がすで に 4 歳児において成人の域に達しており，乙かも 男子が女子を有意に上回っており，さらに5分走 の成績においても男子が女子を有意に凌鴐してい ること ${ }^{22,23)}$ をず明らかにした。ついで 4 〜歳 児の各種走行速度のトレッドミル走行における心 拍数 $(\mathrm{HR})$ と酸素摂取量 $\left(\mathrm{Vo}_{2}\right)$ の変化から, 幼児 において数分間の持久走を安全に導入する走行速


に，種々の走行速度によるトレッドミルオールア ウト走に打ける負荷開始後之負荷終了後の回復時 にみられた $\mathrm{HR}$ と $\dot{\mathrm{Vo}}_{2}$ の变化から，運動負荷に 対する呼吸循環系の応答における幼児の特性と優

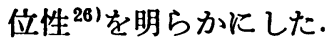

一方, 幼児の日常生活に打ける身体活動の実態

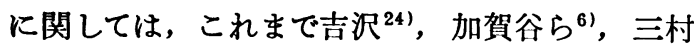


いては, ある 1 日のらちの限られた時間あるいは その24時間を通して記録された HR と，別途に求 められた $\mathrm{HR}-\mathrm{Vo}_{2}$ の関係を対応させるという方 法がとられている.

そこで本研究においては，いわゆる施設収容型 と呼ばれ，狭い空間のなかで日中の殆んどの時 間, ある一定のカリキュラムのもとで生活するこ とを余儀なくされている保育園の幼児を対象に， まずある週の月曜日から土曜日までの園内生活に おける HR を記録した。そしてこうした HRの記 録を,トレッドミル走行による漸增負荷のもとで 求められた従来通りの $\mathrm{HR}$ と $\dot{\mathrm{V}} \mathrm{o}_{2}$ はもとより,
幼児の場合における新しい陚みとして測定された 血中乳酸濃度 $(\mathrm{LA})$ の動態とも関連づけ, 保育園 における身体活動による生理的負荷の実態を明ら かにするとともに，適正負荷強度についての提言 を試みようとしたものである。

\section{II. 研 究 方 法}

\section{A. 被検者}

杤木県那須郡烏山町 $\mathrm{M}$ 保育園の男子 6 名, 女子 7 名の計13名であり, 本研究の目的, 内容を説明 のらえいずれも保護者の承諾を得ている. Table 1 には身体的特長が示されているが，これはトレッ ドミル走行の本実験終了後に計測された值であ る. また当保育園では毎週日の朝, 園外の舗装さ れていない農道で $800 \mathrm{~m}$ のいわゆるマランン（持 久走）を各人各様の走り方で実施しており，これ らの被検者も入園時から参加している.

\section{B. 保育園における HR の記録}

男子の $\mathrm{EH}$ と HS 22 名, 女子の YS と TM の 2 名についてのみ, 昭和 61 年 5 月の第 3 週, 月〜土曜日の午前 9 時からおよそ午後 4 時まで， 心拍メモリ装置 (竹井器機工業 $1850 \mathrm{a}$, 重量 $100 \mathrm{~g}$ ) により，1 分区切りで連続的に記録した．その後 の HR の処理はハートレートアナライザ（竹井器 機工業 $1850 \mathrm{~b}$ ) によって行われた。 また時間経過 にともなら行動や動作の様子をも含めて記録し, それと HRの変化を対応できるようにした。

\section{C. トレッドミル走行による辢增負荷}

まず上記 4 名について，同年 6 月の第 1 週のあ る日, 栃木県総合運動公園トレーニングセンター において予備実験を行った。それは，傾斜なしの トレッドミル上で $\mathrm{ECGV}_{4}$ 誘導による HR の記録 を行いながら，第 1 段階の走行速度を $80 \mathrm{~m} / \mathrm{min}$ 
Table 1. Physical characteristics of subjects.

\begin{tabular}{|c|c|c|c|c|c|c|c|}
\hline \multirow{2}{*}{ Subjects } & \multirow{2}{*}{$\begin{array}{c}\text { Age } \\
\text { (years : } \\
\text { months) }\end{array}$} & \multirow{2}{*}{$\begin{array}{l}\text { Body } \\
\text { height } \\
(\mathrm{cm})\end{array}$} & \multirow{2}{*}{$\begin{array}{c}\text { Body } \\
\text { weight } \\
\text { (kg) }\end{array}$} & \multicolumn{4}{|c|}{ Skinfold thickness (mm) } \\
\hline & & & & Upper arm & Subscapula & Iliacus & Umbilicus \\
\hline \multicolumn{8}{|c|}{ Male } \\
\hline A A & $5: 04$ & 107.6 & 19.10 & 12.0 & 4.5 & 4.0 & 4.0 \\
\hline $\mathrm{SO}$ & $6: 01$ & 121.1 & 20.65 & 9.0 & 5.0 & 4.0 & 3.5 \\
\hline $\mathrm{N} \mathrm{K}$ & $5: 03$ & 105.9 & 18.00 & 9.5 & 6.0 & 8.0 & 5.5 \\
\hline $\mathrm{H} \mathrm{Sr}$ & $5: 11$ & 106.0 & 17.20 & 8.5 & 6.5 & 8.0 & 6.5 \\
\hline $\mathrm{E} \mathrm{H}$ & $5: 05$ & 112.8 & 20.35 & 9.0 & 5.0 & 5.0 & 5.5 \\
\hline $\mathrm{H} \mathrm{S}$ & $6: 03$ & 120.1 & 21.90 & 7.0 & 4.5 & 3.5 & 4.0 \\
\hline$\overline{\mathbf{x}}$ & $5: 08.0$ & 112.3 & 19.53 & 9.2 & 1.6 & 5.4 & 4.8 \\
\hline sd & $: 05.1$ & 6.9 & 1.76 & 1.6 & 0.8 & 2.1 & 1.2 \\
\hline \multicolumn{8}{|c|}{ Female } \\
\hline Y I & $6: 00$ & 108.3 & 16.95 & 10.5 & 5.5 & 5.5 & 4.0 \\
\hline M O & $5: 07$ & 108.0 & 16.15 & 7.5 & 4.0 & 4.0 & 3.0 \\
\hline $\mathrm{K} \mathrm{K}$ & $5: 08$ & 111.6 & 21.45 & 12.0 & 9.0 & 9.0 & 9.5 \\
\hline $\mathrm{H} \mathrm{S}$ & $5: 07$ & 106.1 & 16.15 & 10.0 & 4.5 & 3.5 & 3.5 \\
\hline A $M$ & $5: 09$ & 105.3 & 17.45 & 14.0 & 11.0 & 9.0 & 9.5 \\
\hline Y S & $5: 11$ & 114.5 & 27.95 & 19.0 & 20.5 & 20.0 & 28.0 \\
\hline $\mathrm{T} \mathrm{M}$ & $6: 03$ & 111.7 & 16.20 & 8.5 & 3.5 & 3.0 & 3.5 \\
\hline$\overline{\mathbf{x}}$ & $5: 09.9$ & 109.4 & 18.90 & 12.2 & 8.3 & 7.7 & 8.7 \\
\hline sd & $: 03.0$ & 3.3 & 4.41 & 4.0 & 6.1 & 6.0 & 9.0 \\
\hline
\end{tabular}

として，30秒間の休息を挾みつつ，2 分間 $20 \mathrm{~m} /$ min の溸増負荷による走行を試み，こらした条件 におけるこれら被検者の上限の走行負荷強度を予 じめ知っておくためであった。

ついで 3 日後の本実験においては，まず被検者 をトレッドミル上に固いた椅子に坐らせ，HR 記 録用の電極, 呼吸数記録用のサーミスタがセット された子供用呼気採気マスクを装着した。そのお よそ20分後，坐位のまま 5 分間の呼気採気と HR の記録を行った．その採気終了後, 予じめ血管拡 張剤 (Finalgon, 西独) が叙布された右側耳氺か らキャピラリー (Corning, 米国) により約 20〜 $30 \mu \mathrm{l}$ の採血を行った.

漸増負荷の各段階においては，2 分間持続の最 後の 30 秒間に採気し，またトレッドミル停止によ る走行中止後直ちに採血した.

最終段階に拈いては後半の 1 分間に 30 秒毎に連 続的に採気した。
こうした本実験における人的配直はトレッド ミル操作と計時の係, レコーダー操作係, 呼気採 気係, 呼気量測定と呼気サンプリング係, 採血係, 血液処理係に各 1 名, そして走行中万一転倒しそ らになったり(実際には皆無であった), 最終段階 の走行中そのペースについていけず後ずさりする 場合に直ちに抱き上げることができるように被検 者の直ぐ後で身構えている者 1 名の計 7 名であっ た。

呼気はショランダー微量ガス分析器により，ま た LA はラクテートアナライザ (LA-640 Roche, スイス)によって分析された.

他の被検者 9 名については，こうした漸増負荷 におけるLA の変化の特性をより高い信頼性のも とで把握できるよらに，同じ測定手順により，昭 和 62 年 6 月に追加測定したものである.

なお，いずれの場合も採血は前独協医科大学第 一小児外科助教授, 現池田クリニック院長池田舜 
一氏の指導管理のもとに行われた。

\section{III. 結果及び考察}

\section{A. 運䃼による幼児の LA 功㥿の特性}

各段階の走行持続時間を 2 分間としたのは, 幼 児の呼吸循環系の応答が青少年よりも速く, 各種 走行速度に対して走行開始後 1 分間後でほぼ定常 状態が成立する ${ }^{25}$ からであり，また $\mathrm{ICSPE}^{4)}$ 子 どもの場合そのように推奖している.

Fig. 1 は各種走行速度に対する $\mathrm{HR}, \dot{\mathrm{V}} \mathrm{o}_{2}$ 及び LA の值を, 斜線の部分が意味している有酸素 的一無酸素的移行相の領域とともに図示したもの である.また，これらの適合曲線から求められた LA $3 \mathrm{mmol} / l$ 及び LA $4 \mathrm{mmol} / l$ (以下それぞれ $3 \mathrm{~m}$ MLA, $4 \mathrm{~m}$ MLA とする) に相当する各種変 量の值を, 最終段階の最大努力時における变量と 相対的に比較しながら示したものが Table 2 であ る.

\section{1. 最大努力時 LA}

まず，最終段階の最大努力時において $\dot{\mathrm{V}}_{2} \mathrm{max}$

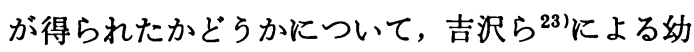
児の場合 HR 200 beats/min 以上, 呼吸商 $(R Q)$ 1.0以上という判定基準と照合してみると, HRで は男子の SO，女子の KK と HS は200 beats/min に達していないが， RQ では男子の SO と女子の $\mathrm{KK}$ は 1.0 に達していたので, $\mathrm{RQ}$ が 0.98 の女子 の HS を除く他の被検者では $\mathrm{V}_{2} \max$ が発現し たものと思われる.こうして得られた $\dot{V}_{o_{2}} \max の$ 平均值は吉沢ら ${ }^{22,23)}$ のトラック走による同年跉の 男子の 49.3 ( 5 歳) 50.5 ( 6 歳) $\mathrm{ml} / \mathrm{kg} / \mathrm{min}$ 及び女 子の 45.6 ( 5 歳) 46.6( 6 歳) $\mathrm{m} l / \mathrm{kg} / \mathrm{min}$ とほぼ一 致している.

そこでこうした最終段階の負荷直後にみられた LA についてみると, Table 2 に示されているよ らに，男子では $5.16 \mathrm{~m} \mathrm{MLA，女子では} 4.70 \mathrm{~m}$

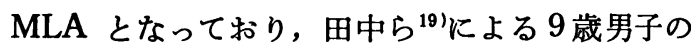
$5.94 \mathrm{~m}$ MLA, 跡見ら" による 11 歳男子の $6.20 \mathrm{~m}$ MLA，そして吉沢ら ${ }^{27)}$ とる14歳男子の $8.56 \mathrm{~m}$ MLA，14歳女子の $8.41 \mathrm{~m}$ MLA よりも低い：こ うしてみると，持久性の最大努力時における LA の值は年歳が低くなるにしたがって徐々に小さく
なっていくといらことがわかる.

その理由としては，子どもでは骨格筋における 有酸素的 TCA 回路に先行する無酸素的解糖系の 酵素活性レベルが成人よりす低く，そのために 産生された乳酸が酸化処理されやすいといら EriKsson $^{21}$ や Weyman ら ${ }^{21)}$ による所見が，さら に低い年齡の幼児では一層強く当て嵌まるのでは ないかということである. その他の理由として考 えられることは, Lehmann ら"11が指摘した最大 努力時における交感神経の活動レベルが幼児では より低いといら事実から，血管収縮が抑制され， したがって肝血流もより大きくなり肝臓における 乳酸の再合成処理が行われやすいこと, また Robinson $^{151}$, 石河 $5^{51}$, Mácek $ら^{121}$, 吉沢ら ${ }^{251}$ б 報告したように，幼児の呼吸循環系の応答の速さ が大きいために運動開始時からみられる酸素不足 $\left(\mathrm{O}_{2}\right.$-deficit $)$ の量が少ないこと,さらに Koch ${ }^{101}$ が示唆したように活動筋における血流量が高いこ と,などである。

\section{2. 最大下負荷に打ける LA}

Mader ら ${ }^{13}$ は成人の 30 分間の走行において, そ の間乳酸の産生とその除去処理のバランスが最高 のレベルで維持される負荷強度（走行速度）を Maxlass と称し，その状態で得られた $4 \mathrm{~m} \mathrm{MLA}$ を無素的閾值(Anaerobic threshold, AT)と呼び, それは同時にさほど無酸素的代謝に落ち入ること なく有酸素的代謝が最大限に動員されている状態 を意味するものであるとしている．したがってこ れに相当する負荷強度が持久性トレーニングの至 適負荷強度として考えられ, その後 Kindermann $5^{91}$, Keul $5^{71}$, Simon $5^{171}$, Stegmann $5^{181} に$ よってその測定が試みられてきた。

本研究に打いては, 幼児では $4 \mathrm{~m}$ MLA の走行 速度で30分持続できるとは思われないが，他の研 究者による他の年龄との比較ができるという理由 から， $4 \mathrm{~m}$ MLA に相当する変量によっても検討 することにした.

そこでまず $4 \mathrm{~m}$ MLA に相当する HR (HR $4 \mathrm{~m}$ MLA)の HRmax に対する比率 (\%HRmax-4 m MLA) についてみると, Table 2 からわかるよら に，男子では $97.5 \pm 1.7 \%$ とっており，それは田 
.

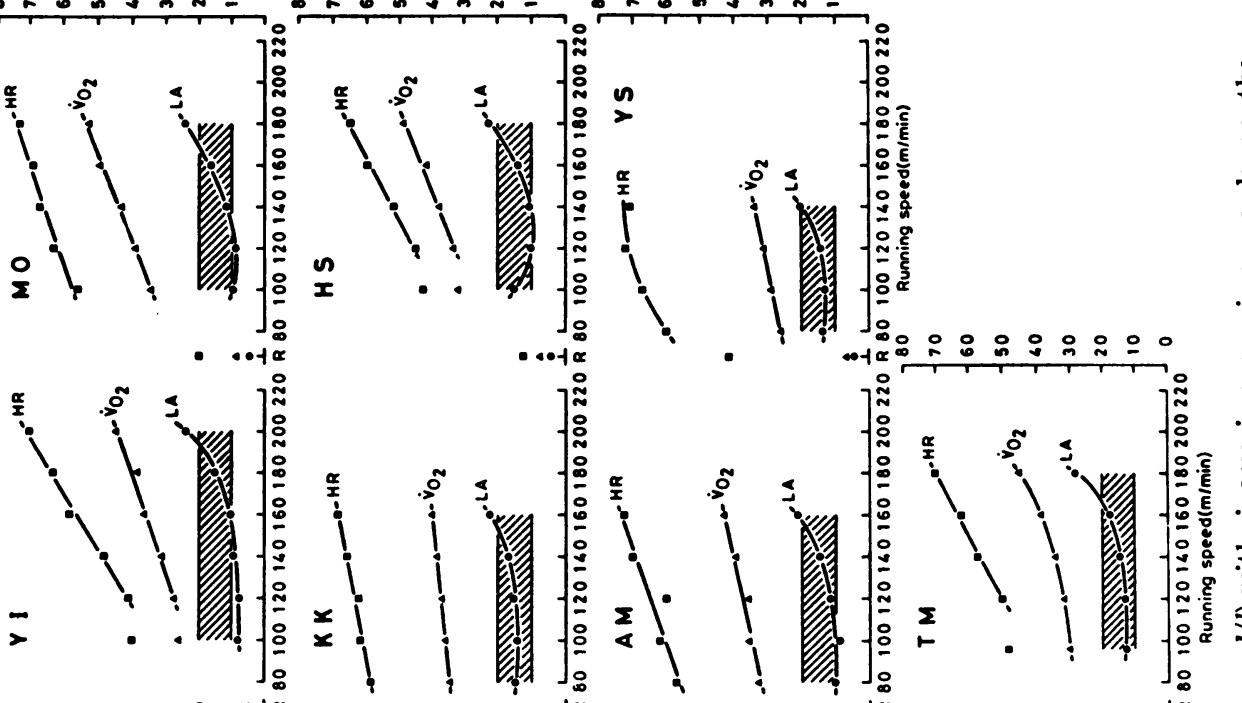

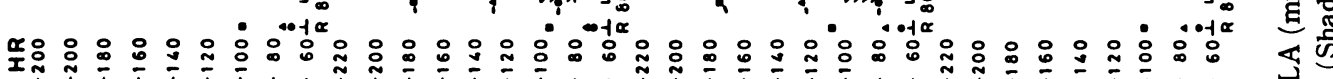

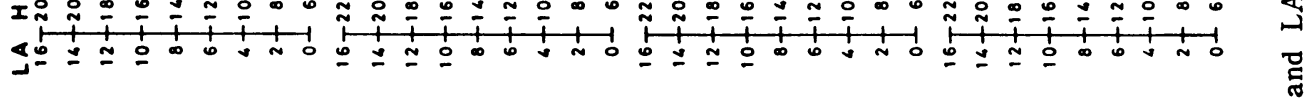
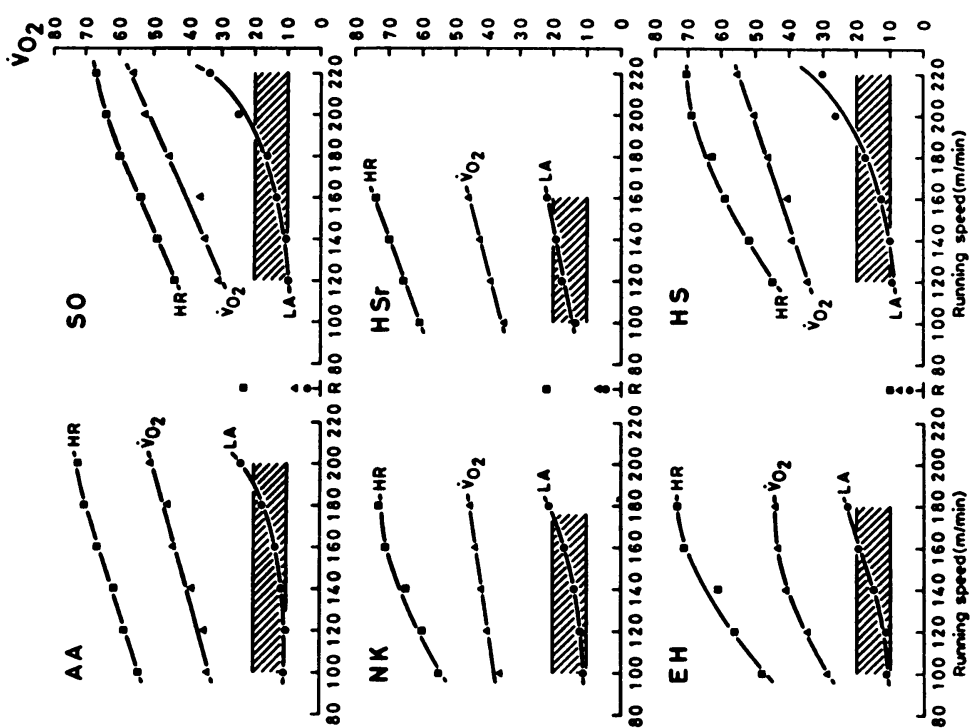


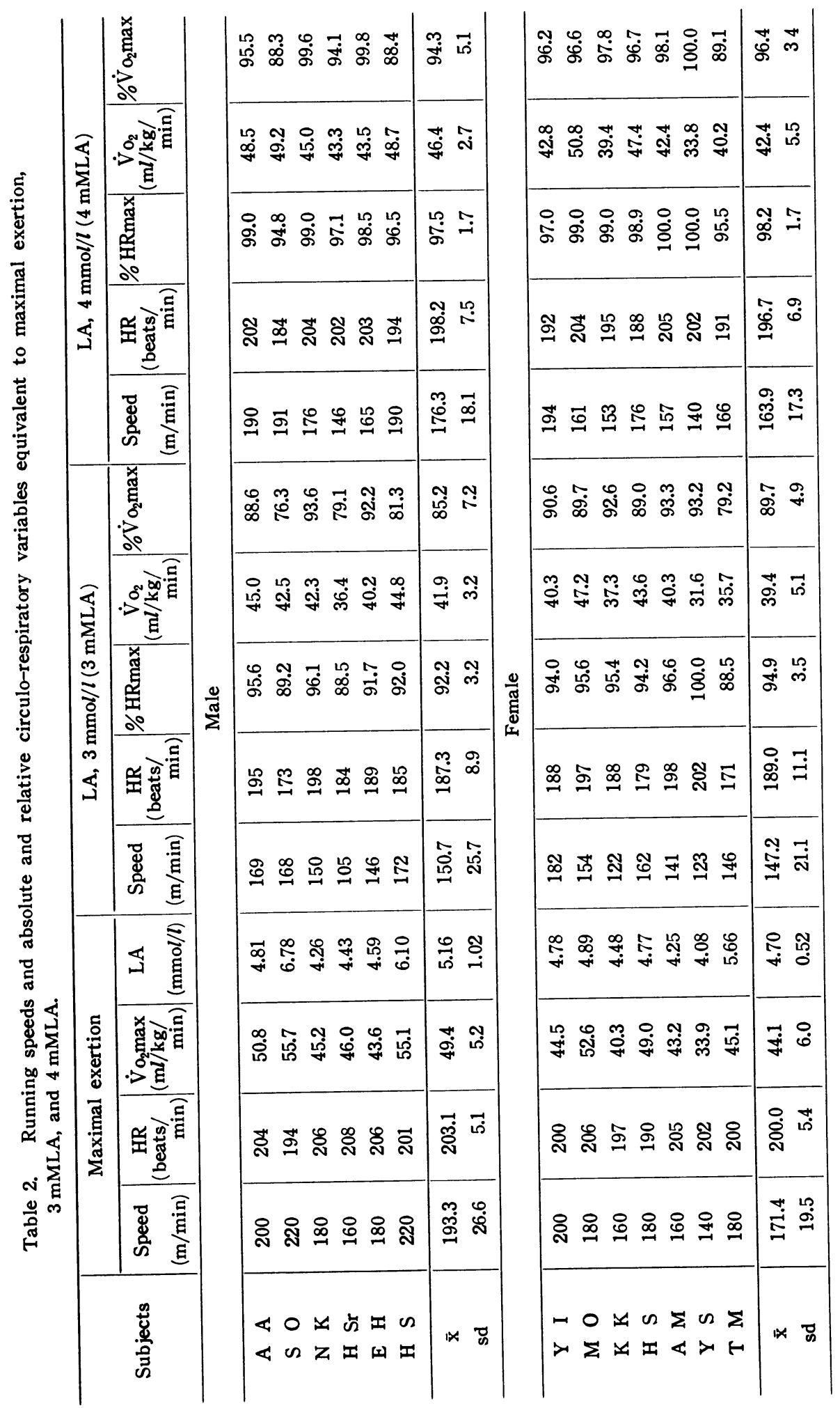


中ら ${ }^{19}$ のトラック走による9歳 $(\mathrm{n}=11)$ の $97 \pm$ $2 \%$ 匹敵しており, 吉沢ら ${ }^{271}$ のトレッドミル走 による14歳 $(n=7)$ の $89.9 \pm 4.5 \%$, 再び田中ら ${ }^{191}$ の 22 歳 $(n=6)$ の $80 \pm 2 \%$ る 高くなってい る. 一方女子では $98.2 \pm 1.7 \%$ となっ扣り，吉沢 ら ${ }^{27)}$ によ 14 歳 $(n=3)$ の $89.6 \pm 6.8 \%$ ๖も高い。

同じょらにして\% $\dot{V}_{2} \max -4 \mathrm{~m}$ MLAについて みると，男子では $94.3 \pm 5.1 \%$ とって扣り，田中 ら ${ }^{191}$ による 9 歳の $90 \pm 10 \%, 21$ 歳の $73 \pm 2 \%$, 吉 沢ら ${ }^{271}$ にる14歳の $85.9 \pm 5.8 \%$ よ高く，女子で

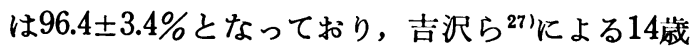
の84.8 $\pm 7.5 \%$ よりも高い.

こうしてみると％ \% HRmax-4 m MLA 及び $\% \dot{\mathrm{V}}_{2} \max -4 \mathrm{~m}$ MLA ともに年齢が低くなるにし たがって高くなり，幼児ではともにほぼ100\%の 值に達していることがわかる.

このように幼児では, ほぼ最高のレベルの強度 に至るまでより有酸素的に代謝が進行しているこ とがわかるが，それには，幼児では HV/TBM 及 び SV/TBM に拈いて成人と差がないにもかかわ らず体重に占める骨格筋の比率が小さいため $\mathrm{HV} / \mathrm{O}_{2}$-pulse の值が高くなるという Kindermann $ら^{8)}$ の報告を考慮すると, 活動筋は豊富な 酸素供給のもとに活動できるといらことがひとつ
の理由として考えられる。

こうしてみると, 幼児の場合, 最大努力時にお いて活動筋は豊富な酸素に恵まれながらも，その 代謝機序においてすでに述べたよらな無酸素的解 糖作用の制約があり，したがって酸素運搬系とし ての心肺機能に余裕を残しながら運動の中止また はその強度の低下を余儀なくされるというょうに 考えられる.このことは, 生体への過重負荷 (Überbeanspruchung) に先行して活動筋が疲労 し, 心臓循環系を保護するという機序が幼児にお いてはより完全に備わっていることを意味するよ らである。

\section{B. HR 及び LA からみた活動水準}

1. 1 日の園内生活に打ける HR の $\overline{\mathbf{x}}$

Fig. 2 には男子 $\mathrm{EH}$ と HS, 女子 YS と TM の 4名について, 園内の生活時間に相当する HRの 記録時間 ( $\mathrm{n}$ 分) と, その $\overline{\mathrm{x}}$ 及び $\mathrm{Sd}$ が相対的生 理的負荷強度とともに矅日ごとに示されている. $\mathrm{EH}$ の場合は気分のすぐれなかった木曜日 の89 beats/min を除くと 102〜114 beats/min, HS の 場合は98〜110 beats/min, YS の場合は123〜126 beats/min そして TM の場合は土曜日のかなり 高い125 beats/min を除けば106〜119 beats/min という值を示した．このように被検者ごとに日間

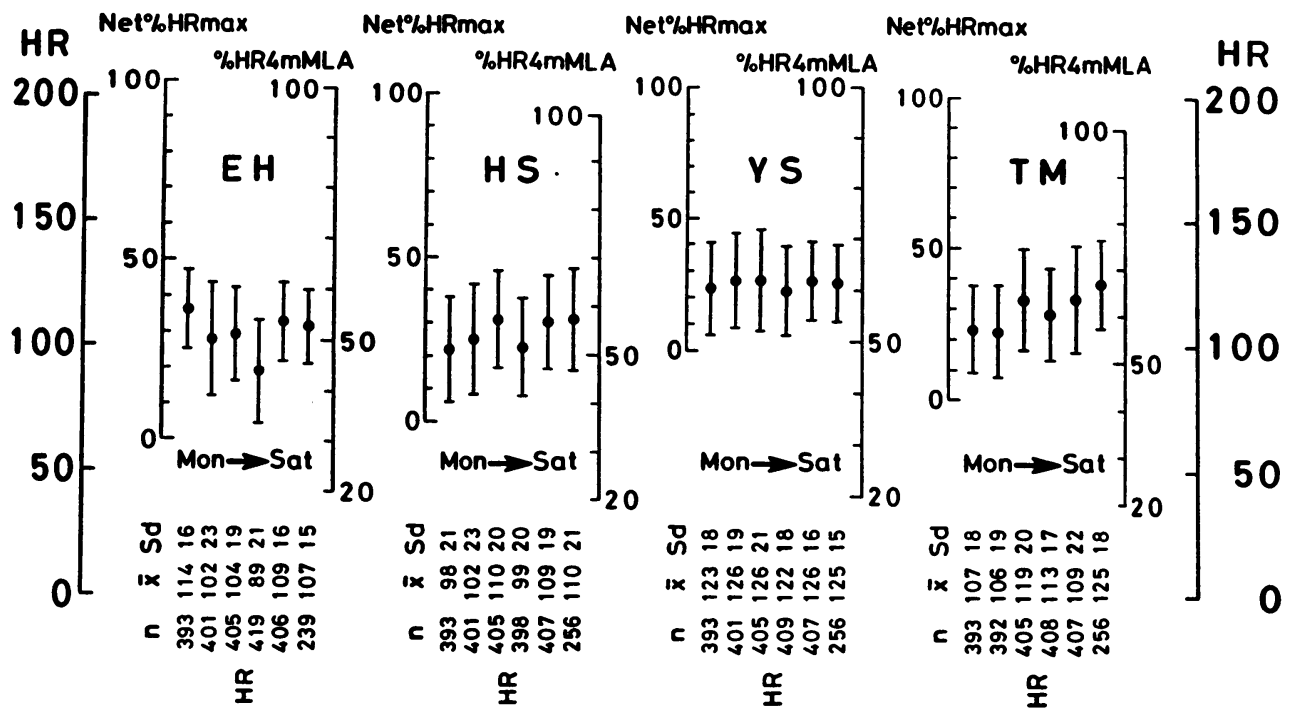

Fig. 2. Mean values of HR recorded in the nursery are shown in comparisons with relative intensities of physiological work load. 
変動がみられるのは, 日々の各行動や動作のパタ ーンあるいはそのなかでの身体活動の水準とその 持続時間の差に負うところが大きいことはいうま でもない.

ところで身長に対する平均体重 ${ }^{201}$ を34\%も上回 っている YS がかなり高い $\mathrm{x}$ を示したのは, 後の Table 3 からわかるように，午睡に括ける $\mathrm{x}$ が 98〜 103 beats/min というょうに他の $\mathrm{HE}$ の62〜 85 beats $/ \mathrm{min}$, HS の $69 \sim 86$ beats $/ \mathrm{min}$, TM の 79 beats $/ \mathrm{min}$ と比較してかなり高く頻脈症の傾 向にあるためである.

こうしてみると，一般的なカリキュラムのもと での保育園内生活に和ける HR の $\overline{\mathrm{x}}$ は100 115 beats/min の範囲にあるすのと思われる．しかし これらの值は三村ら ${ }^{14}$ とよる男子 4 名の幼稚園内 生活に打ける123〜135 beats/min より低いが，そ れは本研究において午睡または横になる (Lying) の時間が設定されていること，また三村らの被検 者が $\dot{\mathrm{V}} \mathrm{o}_{2} \mathrm{max} / \mathrm{TBM}$ の值が示されていないので定 かではないが，本研究の被検者よりも呼吸循環系 の能力に打いて低かったためか，もしそうでない とすれば，その幼稚園における運動がより活発で あったためであろう。

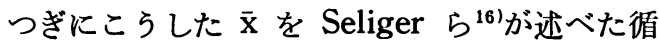
環系への負荷 (Circulation load) という立場から， その方法に準じて Table 2 の HRmax と Table 3 に拈ける午睡のうちでもっとも低いHR の $\overline{\mathrm{x}}$ の 值から

Net $\% \mathrm{HRmax}=$ $\frac{\text { 園内生活の HR の } \overline{\mathrm{x}} \text {-午睡の HR の } \overline{\mathrm{x}}}{\mathrm{HRmax} \text { - 午睡の } \mathrm{HR} \text { の } \overline{\mathrm{x}}} \times 100$

の式により，正味の負荷強度として眺めてみる と，Fig. 2 に示されているょうに，男子では Net 19〜36\% HRmax，女子では Net 22〜38\%と なり，男女ともほぼ同じであった。

しかしそれを一般的なみかけの比率でみると男 子が 43〜 55\% HRmax となり女子の 53〜 63\% HRmax より高く，また LA との係りでは， $4 \mathrm{~m}$ MLA の HR に対する比率すなわち\% HR $4 \mathrm{~m}$ MLA でみると，Fig. 2 に示されているように， 男子が $44 \sim 57 \%$ HR 4 m MLA，女子が57〜 67\%
HR 4 m MLA となっており，いずれも女子が男子 よりも約 $10 \%$ 差をもって高い値を示した。これ

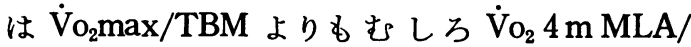
TBM に打いて男子が女子を上回っており，した がってそれは活動筋に打ける代謝機序においてよ り優れていることを意味しているので，共通のカ リキュラムの負荷のもとでは，男子がその分だけ 心㖑血管に余裕を残すことができたためであろ 5.

2. HR のカテゴリーからみた活動水準

Fig. 3 は HR の階級幅を 10 beats $/ \mathrm{min}$ として 上記 4 名の月〜土曜日の園内生活における $\mathrm{HR}$ を，HR 3 m MLA とともに，ヒストグラムで示 したものである.

ところで Gilliam ら ${ }^{31}$ は 6 ～7歳児を対象に12 時間にわたる HRの変化を追っており，そして心 蔵血管系の能力 (Cardiovascular fitness) の改善 をもたらす負荷強度を少なくとも 160beats/min として検討したところ，それを上回った合計時間 は男子では21分，女子では 9 分といらようにかな り短く，また 120 beats $/ \mathrm{min}$ 以下の合計時間は12 時間の $75 \%$ 以上の長さに達したと報告している. 本研究に打いても 160 beats $/ \mathrm{min}$ を上回った合計 時間は, $800 \mathrm{~m}$ 持久走の場合を除くと， $\mathrm{EH}$ の $0 \sim 4$ 分, HS の $0 \sim 6$ 分, TM $0 \sim 6$ 分そし て頻脈症気味の YS ですら 4 21分というように 極めて短いものであった。ちなみに 160 beats/ min 飞相当する LA は, EH では $2.2 \mathrm{~m}$ MLA, HS では $2.0 \mathrm{~m}$ MLA, TM では $2.7 \mathrm{~m}$ MLA となって おり, YS でも Fig. 1 から 2.0〜2.5 m MLA の範 囲にあることが推測されることから，活動筋はそ の代謝に打いてほぼ完全に有酸素的状態で進行し ており，この負荷強度に対してかなり余裕を残し ていることがわかる.

また 160 beats/min に相当する循環系への正味 の負荷は，EH では Net $68 \%$ HRmax，HS では Net 69\% HRmax, TM では Net 67\% HRmax そ して YS では Net 59\% HRmax となっており，こ れまた循環系への負荷強度としてはまたかなり余 裕があるようである.こうしてみると，Gilliam $ら^{3)}$ の 160 beats/min は負荷強度としては軽く, 

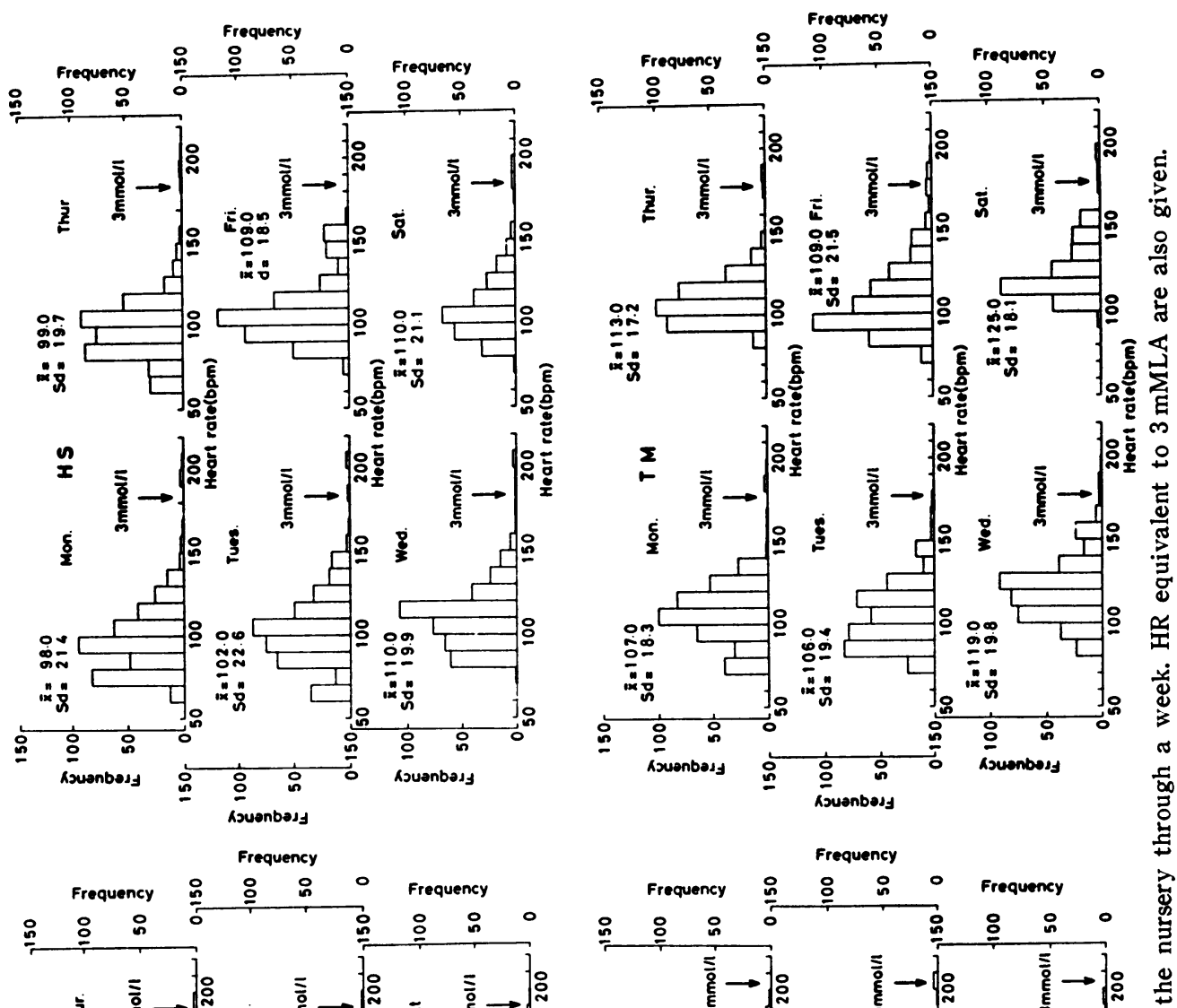



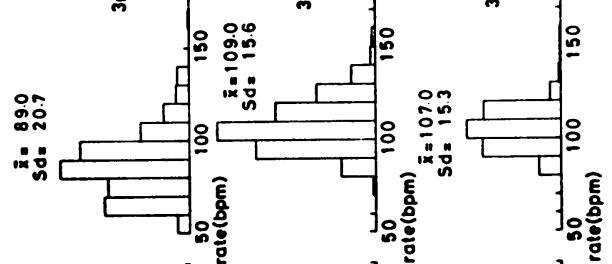
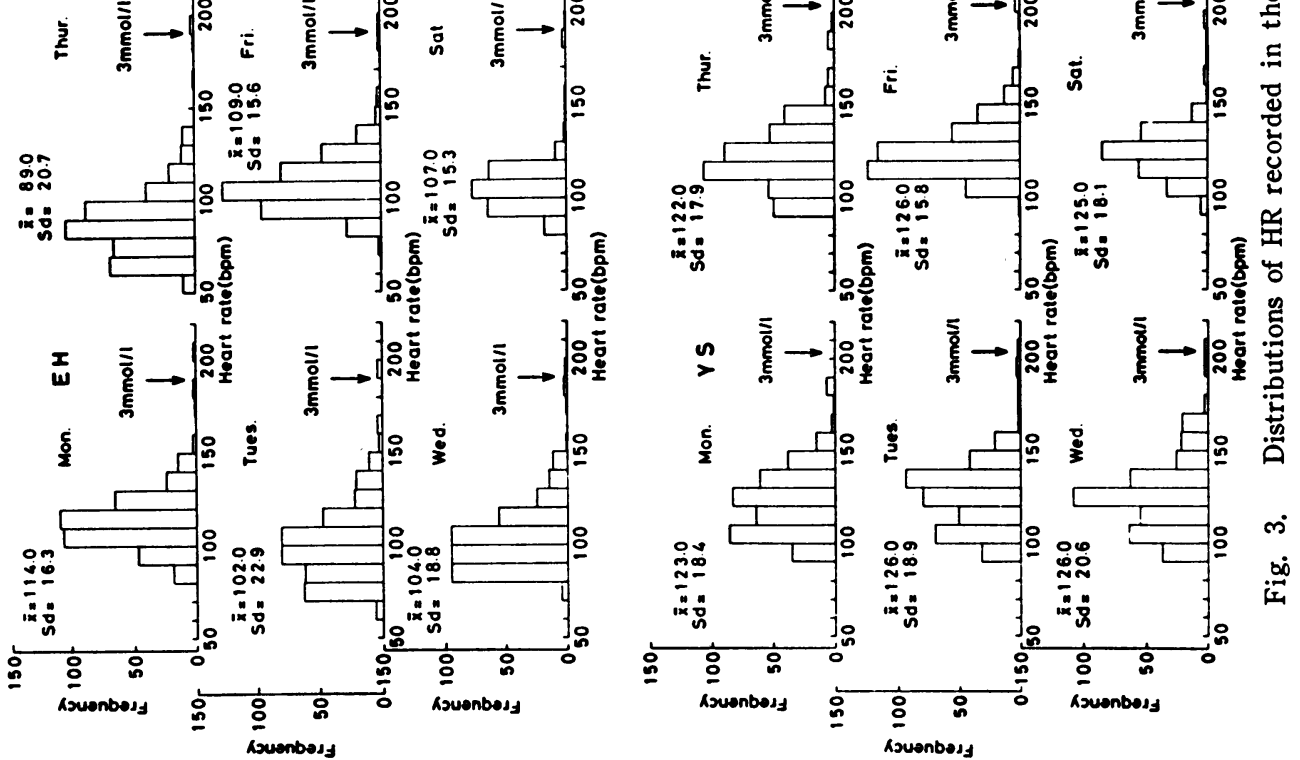

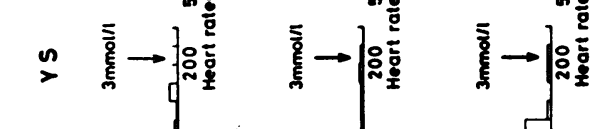
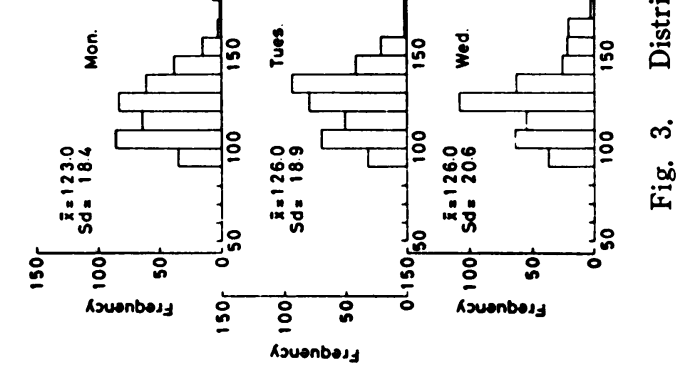


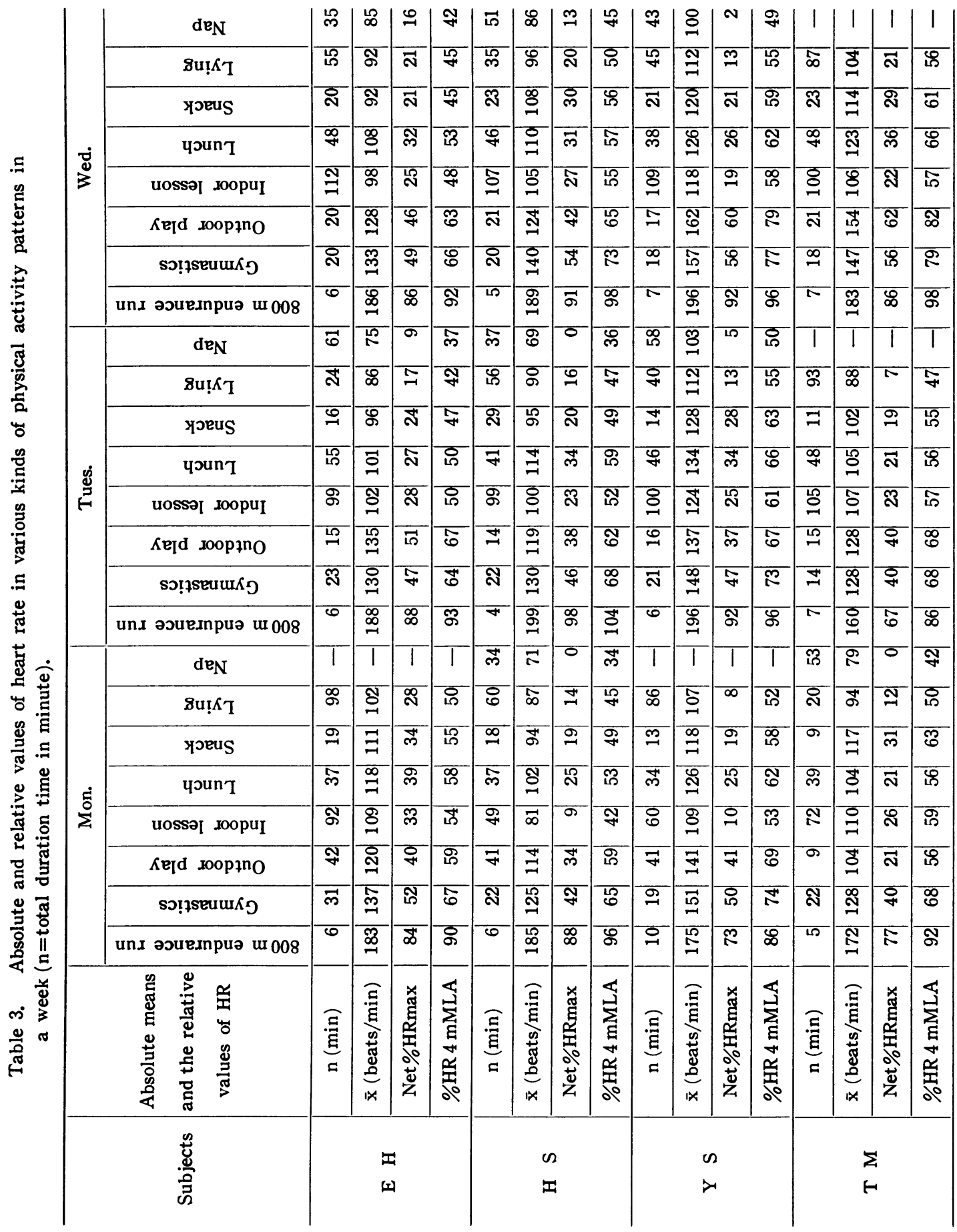




\begin{tabular}{|c|c|c|c|c|c|c|c|c|c|c|c|c|c|c|c|c|c|}
\hline \multirow{8}{*}{$\dot{v}$} & $\mathrm{de}_{\mathrm{N}}$ & 1 & I & 1 & 1 & I & 1 & 1 & 1 & 1 & 1 & 1 & 1 & I & 1 & 1 & 1 \\
\hline & $8 u ! \Lambda_{T}$ & 1 & $T$ & 1 & 1 & 1 & 1 & 1 & 1 & 1 & 1 & 1 & 1 & 1 & 1 & 1 & 1 \\
\hline & Yכous & $T$ & 1 & 1 & $T$ & $T$ & $T$ & $T$ & 1 & $T$ & 1 & $T$ & 1 & $T$ & $T$ & 1 & $T$ \\
\hline & youn 7 & $\bar{\infty}$ & 8 & $\bar{N}$ & T & F్ & के & $\overline{\vec{N}}$ & ธี & $\dot{m}$ & $\underset{\exists}{\exists}$ & $\stackrel{m}{-}$ & Lొ & 아 & $\stackrel{m}{\exists}$ & $\stackrel{\infty}{N}$ & 8 \\
\hline & uosse doopu & $\vec{\infty}$ & $\stackrel{0}{\exists}$ & $\bar{m}$ & $\bar{n}$ & N్ & $\underset{-1}{8}$ & $\stackrel{\infty}{N}$ & 望 & 8 & $\stackrel{\mathfrak{T}}{\sim}$ & $\bar{N}$ & 8 & $\stackrel{2}{20}$ & $\stackrel{\infty}{=}$ & స్ల్ & 8 \\
\hline & Ke & $\stackrel{2}{\sim}$ & $\stackrel{8}{\circ}$ & $\tilde{m}$ & $\pi$ & $\overline{\text { N }}$ & $\stackrel{\theta}{=}$ & $\infty$ & N্চ & $\overline{\mathfrak{N}}$ & స్తి & নి & ஜூర & $\mathscr{N}$ & 㝵 & 남 & $\infty$ \\
\hline & 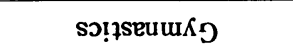 & $\pi$ & $\cong$ & $\stackrel{10}{m}$ & tin & న & $\stackrel{\sim}{\mathscr{I}}$ & $\$$ & 8 & สิ & $\stackrel{\infty}{\mathscr{m}}$ & $\stackrel{\infty}{\infty}$ & $\infty$ & ลี & $\underset{J}{J}$ & เี & $\Sigma$ \\
\hline & unx әэuеxnpuə u 008 & 10 & 节 & $\infty$ & $\bar{\sigma}$ & 10 & $\underset{\sim}{\infty}$ & $\widehat{\infty}$ & 8 & 0 & $\stackrel{\mathscr{N}}{\mathbb{2}}$ & 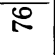 & $\begin{array}{l}\infty \\
\infty\end{array}$ & 0 & $\begin{array}{l}\substack{\infty \\
\infty\\
} \\
\end{array}$ & 8 & 훔 \\
\hline & $\mathrm{deN}_{\mathrm{N}}$ & 1 & 1 & $T$ & 1 & $T$ & 1 & 1 & 1 & 1 & 1 & 1 & 1 & 1 & 1 & 1 & 1 \\
\hline & $8 u ! ̣ K_{T}$ & 1 & 1 & 1 & 1 & 1 & 1 & 1 & 1 & 1 & 1 & 1 & 1 & 1 & 1 & 1 & 1 \\
\hline & yous & $\exists$ & $\bar{\sigma}$ & $\bar{A}$ & $\stackrel{\infty}{+\infty}$ & $\exists$ & $\stackrel{0}{\exists}$ & $\vec{m}$ & in & $\infty$ & $\stackrel{\mathscr{W}}{\stackrel{1}{*}}$ & $\stackrel{\mathscr{N}}{N}$ & $\overline{0}$ & Lo & $\begin{array}{ll}100 \\
=1\end{array}$ & 요 & $\overline{6}$ \\
\hline & youn & הี & ర్త-1 & 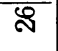 & F & 兽 & $\underset{0}{\mathscr{\gamma}}$ & कి & से & 8 & $\stackrel{m}{=}$ & $\nexists$ & 造 & হి & $\underset{g}{\mathscr{g}}$ & న్ & 4 \\
\hline & uossə] رoopuI & $\infty$ & 8 & \& & 9 & ले & 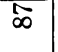 & $\Xi$ & 孚 & $\mathscr{\infty}$ & $\stackrel{10}{\exists}$ & $\mathscr{- 1}$ & ட̊ & F & 边 & $\stackrel{m}{\rightarrow}$ & in \\
\hline & KE[d soopłno & $\stackrel{m}{F}$ & ঙ્తి & P & is & $\overline{\text { in }}$ & 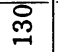 & 栗 & 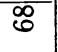 & i̊ & $\Xi$ & $\bar{F}$ & 8 & Tั & 㘿 & 8 & $\frac{10}{2}$ \\
\hline & so!̣seuux & สิ & $\underset{0}{8}$ & ஜ্ল & 范 & $\ddot{n}$ & $\underset{0}{\infty}$ & চ্ল & is & ন & ฟै & F্ & 5 & $\bar{N}$ & $\bar{\Xi}$ & $\vec{m}$ & 8 \\
\hline & und әэuеxnрuə u 008 & 10 & $\underset{\sim}{\mathscr{N}}$ & $\infty$ & ळ & \pm & $\underset{0}{\infty}$ & म्ले & 8 & $\pi$ & S్ & $\infty$ & के & 10 & $\underset{\substack{\infty \\
-1}}{-1}$ & 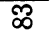 & $\mathscr{\infty}$ \\
\hline \multirow{6}{*}{ 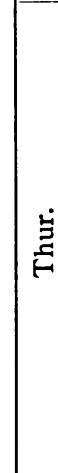 } & deN & 咒 & $\mathcal{ช}$ & 0 & $\bar{m}$ & ח్ & ホ & + & 闬 & ח & $\stackrel{\infty}{\infty}$ & 0 & $\stackrel{\infty}{+}$ & 1 & 1 & 1 & 1 \\
\hline & su!̣ T & P & 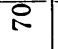 & 5 & लें & i্ & i & $\infty$ & $F$ & $\stackrel{\infty}{\infty}$ & 苛 & 6 & เที & 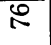 & $\mathscr{\varnothing}$ & $\nexists$ & तु \\
\hline & צ'ёи & $\stackrel{\oplus}{\oplus}$ & $\infty$ & $\stackrel{\infty}{\sim}$ & $\mathscr{Y}$ & $\stackrel{\infty}{\infty}$ & 을 & $\bar{m}$ & is & สิ & $\stackrel{9}{=}$ & กิ & i & $\exists$ & $\stackrel{\infty}{\circ}$ & $\pi$ & 冓 \\
\hline & yวun T & i & $\bar{\sigma}$ & ก & 4 & $\stackrel{\infty}{\infty}$ & $\bar{\circ}$ & $\bar{N}$ & in & ริ & $\stackrel{0}{=}$ & $\simeq$ & in & $\frac{8}{4}$ & $\underset{-1}{\mathscr{7}}$ & ลิ & in \\
\hline & uossə] оорuI & ᄒㅁㅇ & $\infty$ & 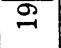 & $F$ & $\mathscr{8}$ & $\pi$ & $\stackrel{9}{-}$ & F & $\tilde{\sigma}$ & స్త & ח & 8 & $\exists$ & $\Xi$ & న & $\overline{6}$ \\
\hline & Ke[d JoopłnO & กิ & 5 & $\pi$ & $\stackrel{\infty}{+}$ & ลิ & 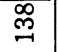 & กิ & N & $\stackrel{L 2}{\sim}$ & $\exists$ & $F$ & 8 & ה & $\overline{\mathfrak{A}}$ & $\stackrel{L}{n}$ & 8 \\
\hline & so!̣seuux & న & $\Xi$ & $\stackrel{\infty}{\infty}$ & 冓 & $\overline{\mathfrak{n}}$ & స్ & O & $\overline{0}$ & ฒొ & $\overline{\mathrm{D}}$ & is & $\approx$ & ส & 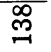 & 9 & $\pi$ \\
\hline & unx əouednpuə ur 008 & in & $\stackrel{\mathscr{\infty}}{\sim}$ & $\Phi$ & 8 & 10 & $\stackrel{\mathscr{\infty}}{\rightarrow}$ & $\infty$ & 48 & 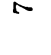 & $\stackrel{10}{\infty}$ & $\infty$ & $\bar{\sigma}$ & 10 & $\vec{\sigma}$ & ஜ & ฮั \\
\hline & 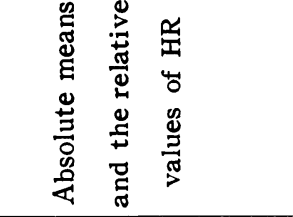 & 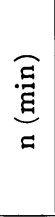 & 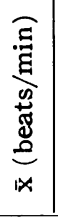 & 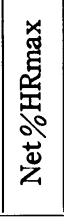 & 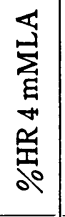 & 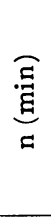 & 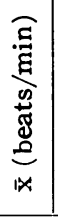 & 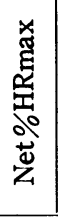 & 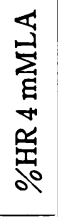 & $\underset{\mathrm{E}}{\stackrel{\widehat{\Xi}}{\mathrm{E}}}$ & 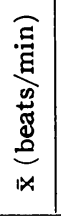 & 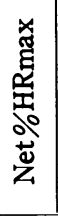 & 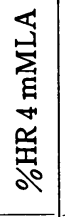 & $\underset{\sigma}{\stackrel{\overparen{\Xi}}{\tilde{E}}}$ & 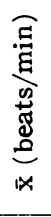 & 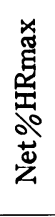 & 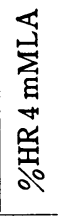 \\
\hline & 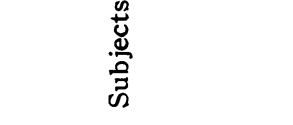 & & ax & & & & & & & & & & & & & & \\
\hline
\end{tabular}


190 beats/min 程度が適切であると考えられる. それは Table 2 からわかるように，有酸素的一無

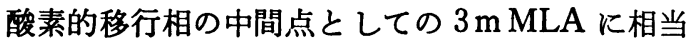
する男子の 187 beats/min, 女子の 189 beats/min にほぼ一致しているからである．また走行速度に するとそれは約 $150 \mathrm{~m} / \mathrm{min}$ に相当している.

さらに 120 beats $/ \mathrm{min}$ 未満の合計時間の園内生 活時間に対する比率は，EH では 72〜94\%，HS では77〜91\%，TM では54〜78\%そして YS です ら34〜70\%といらようにいずれもかなり高い比率 を示している.

したがって,こらした活動水準から判断する
と, 幼児は骨格筋の有酸素代謝機序はいらに及ば ず，循環系ないし心臓血管系においてすら望まし い発達を促進するに足る状況におかれていないの ではないかと思われる.

3. 行動及び動作のカテゴリーからみた活動 水準

Table 3 は同じ 4 名について行動及び動作のカ テゴリー別に合計時間 (n 分), HR の $\overline{\mathbf{x}}$ 及びその Net \% HRmax と\% HR 4 m MLA を矅日ごとに 示したものであり, Fig.4はとのらちの $\overline{\mathrm{x}}$ を図示 したものである.

持久走についてみると，EH では Net 83\%

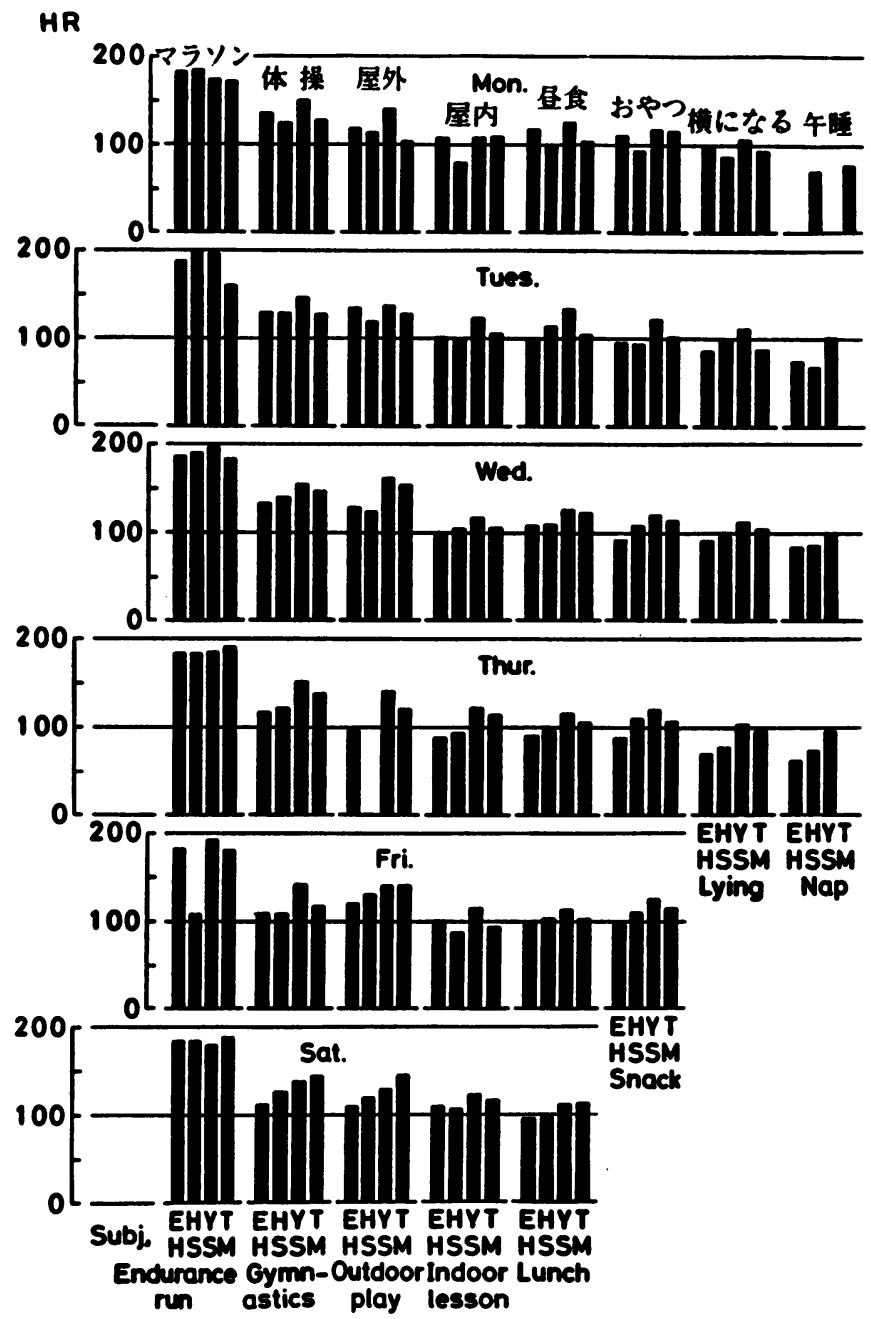

Fig. 4. Mean valeus of HR in various kinds of physical activity patterns in the nursery school through a week. 
HRmax (89\% HR 4 m MLA) Net 91\% HRmax (93\% HR 4 m MLA), HS では Net 86\% HRmax (95\% HR $4 \mathrm{~m}$ MLA) Net 99\% HRmax (104\% HR 4 m MLA), TM では Net 80\% HRmax (86\% $4 \mathrm{~m} \mathrm{MLA}$ ) Net 93\% HRmax-102\% HR4 m MLA) そして頻脈症気味の YS では Net $86 \%$ HRmax (86\% HR 4 m MLA) N Net 96\% HRmax (96\% HR $4 \mathrm{~m} \mathrm{MLA)}$ となっている.これらの值からみると， 持続時間はわずか数分に過ぎないが，こうした持 久走は呼吸循環の発達や改善に大きく寄与してい るものと思われる。

幼児の自然な自発的活動が発現しやすい屋外の 遊びでは, EH が Net 24\% HRmax (48\% HR $4 \mathrm{~m}$ MLA) Net $66 \%$ HRmax (67\% HR 4 m MLA), HS $か$ Net $34 \%$ HRmax (59\% 4 m MLA) Net $52 \%$ HRmax (72\% HR 4 m MLA), TM が Net $21 \% \mathrm{HRmax}$ ( $56 \%$ HR 4 mMLA) Net $62 \%$ HRmax (82\% 4 m MLA)そして YS が Net 29\% HRmax (63\% $4 \mathrm{~m}$ MLA) Net 60\% HRmax $(79 \% \mathrm{HR} 4 \mathrm{~m}$ MLA) といら值を示し，持久走と比較するとかな り低い負荷強度になっている，そのひとつの理由 としては，敷地が小さく，あるひとつの活動の流 れが頻繁に中断されるといら観察上の事実を指摘 することができるが，そのために HRの上昇が必 然的に抑制されたものと思われる.

保母側が働きかけて行わせる体操でも，屋外の 遊びよりるわずかに高い傾向を示したに過ぎず， またその他のパターンにおいてはさらに低くなっ ている.

幼児は， LA に関して\% HRmax-4 m MLA， $\dot{\mathrm{V}}_{2} \% \mathrm{HRmax}-4 \mathrm{~m}$ MLA の值が青少年よりも高 く，それぞれ 100\% HRmax, 100\% $\dot{V}_{o_{2}} \max$ に匹 敵しており，また骨格筋が豊富な酸素の供給のも とで活動できるということから, 活発に活動して も代謝上の疲労に落ち入りにくいといら特性をも っているものと考えられる. それにもかかわら ずこれまで述べてきたような低い活動水準は， いわゆる施設収容型の保育園ならびに幼稚園にお いても類推することができるので，発育にともな う呼吸循環系の健全な発達を促進するには, 予防 医学的立場と相俟って, 特別なプログラムを組み
入れる必要がある. とくに無酸素的解糖系の発達 により以前にも增して大きなパワーを発揮できる よらになってくる思春期を，その受け血としての 有酸素的能力を十分に発達させた上で安全に迎え ることができるように，持久性の負荷を規則的， 継続的に与えることが望まれる。

（受付 昭和62年 7 月16日）

\section{考文 献}

1) Atomi, Y., K. Iwaoka, H. Hatta, M. Miyashita and Y. Yamamoto(1985) : Daily physical activity levels in preadolescent boys related to $\dot{\mathrm{V}}_{2} \max$ and lactate threshold. Eur. J. Appl. Physiol., 55, 151161.

2) Eriksson, B. O. (1972) : Physical training, oxygen supply and muscle metabolism in 11-13 years old boys. Acta Physiol. Scand. Supp. 384.

3) Gilliam, T. B., P. S. Freedson, D. L. Geenen and B. Shahraray (1981): Physical activity patterns determined by heart rate monitoring in 6-7 yearold childern. Med. Sci. Sports Exercise, 13, 65-67.

4) ICSPE (1982) : Revidierte Standardisierungsvorschläge für Ergometrie 1981. Dtsch. Z. Sportmed., 33, 52-52.

5) 石河利寛, 形本静夫, 村岡 功(1981)：幼児の運動 開始時における酸素摂取量および心拍数応答特徵. 体育の科学, 31, 260-264.

6) 加賀谷淳子, 横関利子(1981)：幼児の日常生活の運 動量. 体育の科学, 31, 245-252.

7) Keul, J., G. Simon, A. Berg, H. H. Dickhuth, I. Goertler and R. Kubel (1979) : Bestimmung der individuellen anaerobe Schwelle zur Leistungsbewertung und Trainingsgestaltung. Dtsch. $Z$. Sportmed., 30, 212-218.

8) Kindermann, W., J. Keul, G. Simon and H. Reindell (1978) : Anpassungserscheinungen durch Schulund Leistungssport im Kindesalter. Sportwissenschaft, 8, 222-234.

9) Kindermann, W., G. Simon and Keul, J. (1979) : The significance of the aerobic- anaerobic transition for the determination of work load intensities during endurance training. Eur. J. App. Physiol., 42, 25-34. 
10) Koch, G. (1974): Muscle blood flow after ischemic work and during ergometer work in boys aged 12 years. Acta Pediatr. Belgica, 28(Supp.), 29-39.

11) Lehmann, M., J. Keul and U. Korsten-Reck (1981): Einfluss einer stufenweisen Laufbandergometrie bei Kindern und Erwachsenen auf die Plasmacatecholamine, die aerobe und anaerobe Kapazität. Eur. J. Appl. Physiol., 47, 301-311.

12) Mácek, M. and J. Vávra (1980) : The adjustment of oxyegn uptake at the onset of exercise. Int. J. Sportsmedicine, 1, 70-42.

13) Mader, A., H. Liesen, H. Heck, H. Philippi, P. M. Schurch and W. Hollmann (1976) : Zur Beurteilung der sportartspezifischen Ausdaurleistungsfähigkeit. Sportarzt Sportmed., 27, 80-88.

14）三村寛一，上林久雄(1985)：幼児の日常生活におけ る至遥運動量に関する基礎的研究一24時間の心拍数 の変動について一. 体力科学, 34, 201-210.

15) Robinson, S. (1939) : Experimental studies of physical fitness in relation to age. Arbeitsphysiol., 10, 263-268.

16) Seliger, V., Z. Trefny, S. Bartunková and M. Pauer(1974): The habitual activity and physical fitness of 12 year old boys. Acta Pediatr Belgica, 28(Suppl.), 54-59.

17) Simon, G., A. Berg, H. H. Dickhuth, A. Simon-Alt and J. Keul (1981) : Bestimmung der anaeroben Schwelle in Abhängigkeit vom Alter und von der Leistungsfähigkeit. Dtsch., Z. Sportmed, 32, 714.
18) Stegmann, H., W. Kindermann and A. Schnabel (1981) : Lactate kinetics and individual anaerobic threshold. Int. J. Sports Medicine, 2, 160 165.

19）田中宏曉，進藤宗洋，志波和美，小野敏郎，梶山彦 三郎, 粐井勇次 (1981)：血中乳酸渾度と走行スピー ドとの関係についての 9 歳男児と成人の比較. 体育 科学, 9, 27-33.

20）栃木県全幼雅園連合会：幼児運動機能の発達.

21) Weyman, M., T. Reybouck, H. Stijins and J. Knops (1985): Influence of age and sex on the ventilatory anaerobic threshold in children. Children and Exercise XII, 114-118.

22）吉沢茂弘, 石崎忠利, 本多宏子(1975)：幼児の有酸 素的作業能に関する研究 (I ), 体力科学, 24, 3744.

23）吉沢茂弘，本多宏子(1979) : 幼児の有酸素的作業能 に関する研究 (II )，体力科学，28，104-111.

24）吉沢茂弘(1981)：子どすの運動遊びと呼吸循環機能 の発達. 体育の科学, 31, 316-323.

25）吉沢茂弘，本多宏子，漛原誠，中村 仲(1981)： 幼児の有酸素的作業能に関する研究 (III), 体力科 学, 30, 73-85.

26）吉沢茂弘，本多宏子，涷原 誠(1984)：幼児の有酸 素的作業能に関する研究 ( N ), 体力科学, 33, 173183.

27）吉沢茂弘, 岡 誠一, 宗像茂, 平松和已(1987)： 無酸素的閥値の心拍数による中学校体育授業と部活 動の分析. 宇都宮大学教育学部紀要, 第37号第 2 部 169-209. 